\title{
Effectiveness of Pleidooi by The Supreme Of Criminal Murder
}

\section{Muhammad Baharuddin*) and Akhmad Khisni**)}

${ }^{*}$ S Student of Masters (S2) of Law Faculty of Law Unissula and Civil Servants of the Attorney General's Office, Kudus District, email: bahar adyaksa@yahoo.co.id $\left.{ }^{* *}\right)$ Faculty of Law, Universitas Islam Sultan Agung (UNISSULA) Semarang

\begin{abstract}
The purpose of this study is to study and analyze the effectiveness of the pleaqs submitted by the accused as the perpetrator of the crime of murder in the trial process. In this research, the writer used sociological juridical method with the research specification in the form of descriptive analysis. The data used for this research are primary and secondary data. Based on the results of the research which concluded that in the analysis of the trial process of the verdict in the murder case with the perpetrator Hamim in accordance with the series of decisions Number: 73 / PID.B / 2015 / PN.Kds, the Judge gave a heavier verdict than the prosecutor's demands by using 2 (Article), each of which causes a different victim, namely the victim who died and was seriously injured in Article 338 of the Criminal Code and Article 351 paragraph (1) of the Criminal Code.

Keywords: Pleidooi Effectiveness, Trial Process, Murder Criminal Act.
\end{abstract}

\section{Introduction}

Article 1 paragraph (3) of the 1945 Constitution of the Republic of Indonesia states that the State of Indonesia is a constitutional state. ${ }^{1}$ This means that all forms of individual behavior are based on applicable law. ${ }^{2}$ Perpetrators of crimes or victims of crime will receive legal action based on applicable laws. A person who is suspected of committing a violation of the law cannot be said to be guilty prior to a legal decision by a permanent judge. ${ }^{3}$

Law is the result of social interaction with lifePublic. Law is a symptom of society, therefore the development of law (arising, changing, disapearing) is in accordance with the development of society. Legal development is a mirror of community development. 4 In order to determine a person in fact guilty, proof is required. This evidence is carried out by law enforcers according to predetermined rules, so that arbitrariness does not occur. ${ }^{5}$ Regulations on how to enforce this material criminal law are known as formal criminal law. Formal criminal law

\footnotetext{
${ }^{1}$ Sulistiyawan Doni Ardiyanto, Eko Soponyono, dan Achmad Sulchan, Judgment Considerations Policy in Decree of the Court Criminal Statement Based On Criminal Destination, Jurnal Daulat $\begin{array}{llll}\text { Hukum, } & \text { Vol.3 } & \text { March } & \text { 2020, url: }\end{array}$ http://jurnal.unissula.ac.id/index.php/RH/article/view/8409/4067

2 Supriyono, Criminology Study of Crime of Fencing the Stolen Goods, Jurnal Daulat Hukum, Vol.3 No.1, March 2020, url: http://jurnal.unissula.ac.id/index.php/RH/article/view/8407/4068

3 Endah Tresyani, Kartika Nurlita, Yunita, Pelaksanaan Pembuktian Tindak Pidana Pembunuhan Berencana di Persidangan Oleh Penuntut Umum Kejaksaan Negeri Surakarta, UNS, Jurnal Verstek, Vol.2 No.2, 2014, p. 156

${ }^{4}$ Suwanto, Sri Kusriyah, dan Bambang Tri Bawono, Criminal Aspects Of The Fiduciary Guarantee Transfer As Decision Basis On Criminal Justice Process, Jurnal Daulat Hukum, Vol.3 No.1, March 2020, url: http://jurnal.unissula.ac.id/index.php/RH/article/view/8405/3940

5 Fachrul Rozi, Sistem Pembuktian Dalam Proses Persidangan Pada Perkara Tindak Pidana, Jurnal Yuridis, University of Adiwangsa Jambi, Vol.1 No.2, December 2018, p. 20
} 
regulates who is authorized to do evidence, how to prove it, what can be used as evidence, how people are suspected or charged with committing a criminal act, and determine who is authorized and how to implement court decisions. ${ }^{6}$

In the guidelines for implementing the Code of Procedure, it explains the objectives of the Criminal Procedure Code, namely the purpose of the criminal procedural law is to seek and obtain or at least approach material truth. ${ }^{7}$ It is the complete truth of a criminal case by applying the general provisions of the Criminal Procedure Code honestly and accurately ${ }^{8}$, with the aim of finding out who is the perpetrator who can commit a violation of the law, who then asks for an examination and decision from the court to find out whether it is proven that a criminal act has been committed and whether the person accused can be blamed. ${ }^{9}$

Based on the principle of the presumption of innocence, which means that every person who is suspected, prosecuted and charged or tried before a court must be considered innocent before a Court decision has declared their guilt and has obtained definite legal force. So it is clear and natural that the defendant because of his position is obliged to have his rights. ${ }^{10}$

In an examination of a criminal case before a trial, after the Public Prosecutor has read the charges to the Defendant, the Defendant and / or his Legal Counsel will be given the right to submit a plea. The plea of defense (pleidooi) itself aims to provide an analysis of the process of examining the case against the Defendant and / or his Legal Counsel for later consideration by the Panel of Judges in deciding the case. Before reading the defense note from the Legal Counsel, the Defendant was given the opportunity to read the clause. In principle, a defendant is someone who is prosecuted, examined and tried in a court session. A defendant has committed a violation of the rights of another person which is against the public order.

In this case, seeing the form of the crime of murder itself as a crime that has a heavy weight in the accountability of the speech, however the defendant's rights in the judicial process are still given in accordance with the law, including a plea for the accused.

\section{Research Methods}

This research uses a sociological juridical approach, namely research that uses a method of approaching the problem by looking at the norms or laws that apply as positive provisions, along with the relevant theories of this paper by linking its implementation to the facts in the field. The research specification used is descriptive analysis research, which is research that seeks to describe a symptom, events and events that are happening now. The data used for this research are primary and secondary data.

\footnotetext{
6 Surya Dharma Jaya, Ida Bagus, dkk, 2015, Buku Ajar \& Klinik Manual Klinik Hukum Pidana Fakultas Hukum Universitas Udayana, Udayana University Press, Denpasar,, p. 70.

${ }^{7}$ Rusli Muhammad, 2007, Hukum Acara Pidana Kontemporer, Bandung, Citra Aditya Bakti, p. 192

${ }^{8}$ Adhami Chazawi, 2008, Hukum Pembuktian Tindak Pidana Korupsi, Bandung, Alumni, p. 30

${ }_{9}^{9}$ Andi Hamzah, 2008, Hukum Acara Pidana Indonesia, Edisi Kedua, sinar Grafika, Jakarta, p. 18

10 M. Yahya Harahap, 2006, Pembahasan Permasalahan Dan Penerapan KUHAP Penyidikan dan

Penuntutan, Jakarta, Sinar Grafika, p. 29
} 


\section{Results And Discussion}

\subsection{The Effectiveness of Pleidooi by the Defendant as a Murderer in the Trial Process}

A defendant is given a set of rights regulated in the Criminal Procedure Code. In accordance with its objectives, the Criminal Procedure Code provides justice and protection of human rights in balance with the public interest, including for someone who is made a defendant. ${ }^{11}$ In this study, the rights of the defendants to be analyzed in the implementation of criminal justice are the rights of the defendants in the form of a note of defense (pleidoo). Pleidooi is the last resort of a defendant or defense in order to defend the rights of his client, to defend the truth he believes, according to the evidence revealed in the trial. The last resort means the efforts of the defendant or defense in the trial of the case, before a decision is made by the District Court. ${ }^{12}$

A defense is basically made by the defendant himself by refusing, refuting, and fighting back before the trial. ${ }^{13}$ The legal basis for Pleidooi is regulated in Article 182 paragraph (1) letter b of the Criminal Procedure Code, which states that the defendant or legal adviser submits a defense that can be answered by the public prosecutor, provided that the defendant's legal advisor always has the last turn. Article 182 paragraph (1) letter c of the Criminal Procedure Code stipulates that the charges, defense and answers to the defense are made in writing and after being read out they are immediately submitted to the head judge at trial, in the event that the defendant cannot write, the clerk shall record his defense.

According to Uly Rifi, in filing a defense / pleading, the defendant and / or legal advisor submitted a response, including:

a. The public prosecutor's indictment is vague;

b. The public prosecutor made a mistake in stating the law or article being accused;

c. The public prosecutor made a mistake in analyzing the elements of the offense charged and applying it to the actions of the defendant which were deemed proven;

d. The public prosecutor made a mistake in assessing evidence or using evidence that does not support each other;

e. The offense charged is a material offense not a formal offense;

f. Submit an alibi at the time of the crime;

g. The defendant's actions were not criminal acts;

h. The evidence submitted does not belong to the defendant, and so on. ${ }^{14}$

\footnotetext{
11 Supriyanta, KUHAP dan Sistem Peradilan Pidana Terpadu, Jurnal Hukum, UNISRI, Vol.VIII No.2, April 2009, p. 11

12J Jeremias Lemek, 2009, Penuntun Praktis Membuat Pledoi, print-2, New Merah Putih, Yogyakarta, p. 16

13 Johar Moidadi, Peranan Saksi yang Menguntungkan Terdakwa Dalam Proses Pemeriksaan Perkara Pidana (Studi PN Palu Nomor 10/Pid.Sus-Tipikor/2013/PN.PL), Jurnal Ilmu Hukum Legal Opinion, Edition I Vol.4, 2016, p. 8

${ }^{14}$ Interview with Singgih Wahono SH, Chair of the Kudus District Court, on June 16, 2020
} 
However, in this study, whether the role of pleidoo is effective in a murder trial where evidence is the basis for the judge's consideration in considering a plea of the accused who is a murderer to get the lightest sentence. Seeing the crime of murder as an act that is deemed inhuman in the scope of intentional or planned because of the loss of human life when it is correlated with the essence of a pleidoo as a defense in the sense that an inhuman act still asks for a leniency from a pleidoo.

In an example of a murder crime case as an illustration of the effectiveness of a plea of the defendant in what the defendant can do through his legal advisor with elements of defense that can be submitted before the judge's decision is taken as in the decision Number: 73 / PID.B / 2015 / PN.Kds in the form of:

After hearing the reading of the criminal charges submitted by the Public Prosecutor, which are basically as follows:

a. To declare that the defendant HAMIM bin DAWAM has been legally and convincingly proven guilty of committing a criminal act "deliberately taking the life of another person and committing maltreatment", as stipulated and threatened with criminal charges in violating Article 338 of the Criminal Code and Article 351 Paragraph (1) of the Criminal Code;

b. Imposing the sentence against the defendant HAMIM bin DAWAM in the form of imprisonment for 14 (fourteen) years reduced while the defendant is in temporary detention and under the order of the defendant to remain detained;

c. How much evidence states:

1) 1 (one) sharp spear-shaped weapon, which is pointed and rusty with a length of approximately 40 (forty) $\mathrm{cm}$;

2) 1 (one) spear holster made of black wood tied to a white plastic rope.

Seized to be destroyed and

1) 1 (one) white t-shirt that is already brown in color, with 6 torn marks on the back / back;

2) 1 (one) blue basic color batik cloth with a black and white batik motif with a torn mark in two places on the back;

3) 1 (one) pair of gray shorts with a black stripe on the side of the pants;

d. To stipulate that the defendant must pay a court fee of Rp. 2000 (two thousand rupiah). ${ }^{15}$

In this case, the defendant Hamim for the criminal charges mentioned above, through his legal advisor has submitted a written defense (pleidooi) on June 24, 2015, essentially asking the Panel of Judges to pass the lightest sentence because the Defendant was aware of his mistake and promised not to. will repeat it again and have family responsibilities. After the judge heard the public prosecutor's verbal response to the defendant's pleidoo, the public prosecutor remained on his demands. After hearing the defendant's response through his legal advisor to the response of the Public Prosecutor, which in essence remained on defense (pleidoo). ${ }^{16}$

The case in the criminal case can be said to be a serious crime related to murder and maltreatment with the indictment given by the Public Prosecutor

15 Excerpt of Decision Number: 73 / PID.B / 2015 / PN.Kds

16 Ibid. 
compiled on a cumulative subsidiarity charge which affects the effectiveness of a pleidoo submitted by the defendant as a form of defense in obtaining leniency with all alibis. who can help the accused. The indictment is in the form of:

\section{One:}

\section{Primair}

That the defendant HAMIM bin DAWAM on Wednesday 31 December 2014 at around 07.30 WIB or at least at some time in December 2014 was located at Jl.Kampung RT 01 RW 04 Gang 19, also in Undaan Lor Village, Kec. Undaan Kab. Holy,deliberately taking someone else's life, which was carried out by the defendant in the following ways:

- That it started on Wednesday 31 December 2014 at around 07.30 WIB, when Mr.NAJIB came to the defendant's house with the intention of advising the defendant about the behavior of the defendant which was disturbing the neighbors, but the defendant asked Mr.NAJIB to also advise the neighbors who were in front of the house each of them, namely Mr. GUFRON, Mr. SLAMET and the victims of ZAMAWI and then Mr. GUFRON, Br. SLAMET and the victim ZAMAWI approached the defendant's house and while they were on the village road RT 01 RW 04 Gang 19 they joined Undaan Lor Village. Indaan Subdistrict, Holy District, suddenly the defendant got angry and became angry and then took a sharp weapon, the type of spear that was on the defendant's motorbike, and then the defendant chased after Mr.

- Whereas at that time Mr.NAJIB and Mr.AMAT MUSTAFIAN, who saw the defendant's action when stabbing the victim ZAMAWI did not dare to intervene and Mr. AMAT MUSTAFIAN only shouted "uwes-uwes, ojo-ojo (already, maybe) repeatedly, however the defendant ignored it.

- $\quad$ That the ZAMAWI victim was then taken by Mr. Najib with the residents to the Mardi Rahayu Kudus Hospital to get treatment and during the treatment carried out at the Mardi Rahayu Hospital, the ZAMAWI victim finally died on Sunday, January 4, 2015 at 16.15 WIB at Mardi Hospital Rahayu. The injuries suffered by victims of ZAMAWI are in accordance with the Visum Et Repertum Number: 033 / DIRMP-A4 / I / 2015 dated January 6, 2015 which was made and signed by Dr. Hadi Winoto, Sp.B, a doctor at Mardi Rahayu Kudus Hospital. Whereas based on the expert's statement, namely Dr. Hadi Winoto, Sp.B, the death of the victim of ZAMAWI was not due to other diseases, but because of the tearing stab in the left lung which resulted in profuse bleeding.

\section{Subsidair}

As regulated and punishable under Article 338 of the Criminal Code. ${ }^{17}$

That the defendant HAMIM bin DAWAM on Wednesday 31 December 2014 at around 07.30 WIB or at least at some time in December 2014 was located at Jl.Kampung RT 01 RW 04 Gang 19, also in Undaan Lor Village, Kec. Undaan Kab. Kudus, committed persecution that resulted in death, which was carried out by the defendant in the following ways:

(Same chronology as the primair indictment)

\footnotetext{
${ }^{17}$ Excerpt of Decision Number: 73 / PID.B / 2015 / PN.Kds
} 
As regulated and subject to criminal sanctions in Article 351 Paragraph (3) of the Criminal Code. ${ }^{18}$

\section{Second}

That the defendant HAMIM bin DAWAM on Wednesday 31 December 2014 at around 07.30 WIB or at least at some time in December 2014 was located at Jl.Kampung RT 01 RW 04 Gang 19, also in Undaan Lor Village, Kec. Undaan Kab. Kudus, committed persecution, which was carried out by the defendant in the following ways:

- Whereas it started on Wednesday 31 December 2014 at around 07.30 WIB, when Mr.NAJIB came to the defendant's house with the intention of advising the defendant about the behavior of the defendant which was disturbing his neighbors, but the defendant asked Mr.NAJIB to also advise his neighbors who felt that Uneasy because of the defendant's behavior, then Mr.NAJIB came out of the defendant's house and called the neighbors who were in front of their respective houses, namely Mr. GUFRON, Mr. SLAMET and the victim ZAMAWI then Mr. GUFRON, Mr. SLAMET and the victim ZAMAWI approached the house of the defendant and while on Jalan Kampung RT 01 RW 04 Gang 19 participating in Undaan Lor Village, Kec. Indaan, Kab.Kudus, suddenly the defendant got emotional and angry who then took a sharp weapon, the type of spearhead that was on the motorbike the defendant then the defendant chased after Mr.GUFRON by brandishing a sharp spear-type weapon held in his right hand while saying "no pateni kowe-not pateni kowe" (I kill you-I kill you) and immediately jabbed the spearhead 1 (one) time hitting your right buttock. .GUFRON until he fell, then Mr.GUFRON secured himself because he was in pain.

- Whereas as a result of the defendant's actions, Mr. GUFRON was injured in accordance with Visum Et Repertum Number: 440 / 07.B / I / 2015 dated January 20, 2015 which was drawn up and signed by Dr. Aris Slamet Wahabi, a doctor at Puskesmas Ngemplak, Kudus Regency with the conclusion: "The patient's name is GUFRON bin ISMAIL, Indonesian nationality, Javanese ethnicity, abrasion left elbow, right buttock scar one centimeter long".

As regulated and subject to criminal sanctions in Article 351 Paragraph (1) of the Criminal Code. ${ }^{19}$

Based on the indictment, the judge in the case ruling in the decision Number: 73 / PID.B / 2015 / PN.Kds is based on Article 338 of the Criminal Code (KUHP) and Article 351 paragraph (1) of the Book of Law. Criminal Law (KUHP) and other relevant legal provisions, adjudicate:

a. To state that the defendant HAMIM bin DAWAM was legally and convincingly proven guilty of committing the crime of murder and ill-treatment;

b. Imposing the punishment to the Defendant is therefore with a prison sentence of 15 (fifteen) years;

c. To determine that the entire period of arrest and detention the Defendant has served is deducted from the sentence imposed;

${ }^{18}$ Excerpt of Decision Number: 73 / PID.B / 2015 / PN.Kds

${ }^{19}$ Excerpt of Decision Number: 73 / PID.B / 2015 / PN.Kds 
d. Determine that the Defendant remains detained;

e. Determine evidence in the form of:

1) 1 (one) sharp spear-shaped weapon, which is pointed and rusty with a length of approximately 40 (forty) cm;

2) 1 (one) spear holster made of black wood with a white plastic rope attached;

3) 1 (one) white t-shirt that is already brown in color, with 6 torn marks on the back / back;

4) 1 (one) blue basic color batik cloth with a black and white batik motif with a torn mark in two places on the back;

5) 1 (one) piece of gray shorts with a black stripe on the side of the pants.

f. To charge the Defendant to pay a court fee of Rp. 2,000.00 (two thousand rupiah). ${ }^{20}$

In the analysis of the trial process of the verdict in the criminal case of murder by the perpetrator of Hamim in accordance with the series of decisions Number: 73 / PID.B / 2015 / PN.Kds according to Uly Rifi, the defense (pleidooi) aims to obtain a judge's decision acquitting the defendant from all charges or release the defendant from all legal charges or at least the lightest criminal sentence. ${ }^{21}$ In the plea submitted by the defendant Hamim through his legal advisor, the aim of which is to request at least the lightest criminal sentence. However, the crime of murder committed by Hamim is based on the accusation of cumulative subsidiarity in which Hamim's actions are a concurrent act of murder in Article 338 of the Criminal Code, namely deliberately taking the life of another person, Article 351 Paragraph (3) of the Criminal Code, namely committing torture that causes death. , and Article 351 Paragraph (1) of the Criminal Code, namely carrying out persecution, in this case the attack carried out by the defendant Hamim, which caused many victims which resulted in a person dying and being seriously injured. This had an impact on the effectiveness of the plea filed by the defendant Hamim which did not affect the leniency of the sentence received.

The judge gave a heavier verdict than the prosecutor's demands by using 2 (Articles), each of which resulted in a different victim, namely the death victim and serious injury in Article 338 of the Criminal Code and Article 351 paragraph (1) of the Criminal Code. In this case the judge decided the heaviest punishment in Article 338 of the Criminal Code with a sentence of 15 years imprisonment in the sense that Hamim's attempts to defend / plead the defendant did not affect the verdict given and remained the maximum sentence of the article charged by the public prosecutor.

Hans Kelsen in his book "general theory of law and state", views law as a social order that can be declared fair if it can regulate human actions in a satisfactory way so that we can find happiness in it. ${ }^{22}$ Hans Kelsen's view is a view that is positivist in nature, the values of individual justice can be identified by legal

\footnotetext{
20 Ibid.

21 Interview with Uly Rifi SH, MH, Functional Prosecutor at the Kudus District Attorney, on June 15, 2020

22 Hans Kelsen, 2011, General Theory of Law and State, translated by Rasisul Muttaqien, Bandung, Nusa Media, p.9
} 
rules that accommodate general values, but still fulfill the sense of justice and happiness for each individual. The correlation of Hans Kelsen's theory is in line with the effectiveness of a plea of the accused of murder in decision Number: 73 / PID.B / 2015 / PN.Kds, in which the judge's decision does not heed the plea of the defendant Hamim because of the weight of the criminal acts committed by Hamim which produces elements the accusation because it caused two victims at the same time with the victim's status, namely the victim died and the victim was injured, this means that the criminal sentence imposed is without any influence from the defendant's efforts to defend / plead with the maximum imprisonment sentence.

\section{Closing}

In the analysis of the trial process of the verdict in the criminal case of murder by the perpetrator of Hamim in accordance with the series of decisions Number: 73 / PID.B / 2015 / PN.Kds, the Judge gave a heavier verdict than the prosecutor's demands by using 2 (Articles), respectively. each of which resulted in different victims, namely the victim who died and was seriously injured in Article 338 of the Criminal Code and Article 351 paragraph (1) of the Criminal Code. In this case the judge decided the heaviest punishment in Article 338 of the Criminal Code with a sentence of 15 years imprisonment in the sense that Hamim's attempts to defend / plead the defendant did not affect the verdict given and remained the maximum sentence of the article charged by the public prosecutor.

For policy makers of laws and regulations, the need to be regulated in the Criminal Procedure Code related to the technicality of filing a defense / pleidoo in a more specific form to provide a clearer explanation to the public in general as a manifestation that the community needs to understand one form of the rights of a defendant in the process the judge.

\section{References}

\section{Books:}

[1] Adhami Chazawi, 2008, Hukum Pembuktian Tindak Pidana Korupsi, Bandung, Alumni

[2] Andi Hamzah, 2008, Hukum Acara Pidana Indonesia, Edisi Kedua, Sinar Grafika, Jakarta

[3] Hans Kelsen, 2011, General Theory of Law and State, translated by Rasisul Muttaqien, Bandung, Nusa Media

[4] Jeremias Lemek, 2009, Penuntun Praktis Membuat Pledoi, Print. 2, New Merah Putih, Yogyakarta

[5] M. Yahya Harahap, 2006, Pembahasan Permasalahan Dan Penerapan KUHAP Penyidikan dan Penuntutan, Jakarta, Sinar Grafika

[6] Rusli Muhammad, 2007, Hukum Acara Pidana Kontemporer, Bandung, Citra Aditya Bakti

[7] Surya Dharma Jaya, Ida Bagus, dkk, 2015, Buku Ajar \& Klinik Manual Klinik Hukum Pidana Fakultas Hukum Universitas Udayana, Udayana University Press, Denpasar

\section{Journals:}


[1] Endah Tresyani, Kartika Nurlita, Yunita, Pelaksanaan Pembuktian Tindak Pidana Pembunuhan Berencana di Persidangan Oleh Penuntut Umum Kejaksaan Negeri Surakarta, UNS, Jurnal Verstek, Vol.2 No.2, 2014

[2] Fachrul Rozi, Sistem Pembuktian Dalam Proses Persidangan Pada Perkara Tindak Pidana, Jurnal Yuridis, University of Adiwangsa Jambi, Vol.1 No.2, December 2018

[3] Johar Moidadi, Peranan Saksi yang Menguntungkan Terdakwa Dalam Proses Pemeriksaan Perkara Pidana (Studi PN Palu Nomor 10/Pid.SusTipikor/2013/PN.PL), Jurnal Ilmu Hukum Legal Opinion, Edition I Vol.4, 2016

[4] Sulistiyawan Doni Ardiyanto, Eko Soponyono, dan Achmad Sulchan, Judgment Considerations Policy in Decree of the Court Criminal Statement Based On Criminal Destination, Jurnal Daulat Hukum, Vol.3 No.1, March 2020, url: http://jurnal.unissula.ac.id/index.php/RH/article/view/8409/4067

[5] Supriyanta, KUHAP dan Sistem Peradilan Pidana Terpadu, Jurnal Hukum, UNISRI, Vol.VIII No.2, April 2009

[6] Supriyono, Criminology Study of Crime of Fencing the Stolen Goods, Jurnal Daulat Hukum, Vol.3 No.1, March 2020, url: http://jurnal.unissula.ac.id/index.php/RH/article/view/8407/4068

[7] Suwanto, Sri Kusriyah, dan Bambang Tri Bawono, Criminal Aspects Of The Fiduciary Guarantee Transfer As Decision Basis On Criminal Justice Process, Jurnal Daulat Hukum, Vol.3 No.1, March 2020, url: http://jurnal.unissula.ac.id/index.php/RH/article/view/8405/3940

\section{Interview:}

[1] Interview with Singgih Wahono SH, Chair of the Kudus District Court, on June 16,2020

[2] Interview with Uly Rifi SH, MH, Functional Prosecutor at the Kudus District Attorney, on June 15, 2020 